\title{
Food store loyalty: Application of a consumer loyalty framework
}

Received: 10th September, 2003

\section{Patricia Huddleston}

is a professor of merchandising management at Michigan State University. Her research interests include retail distribution and consumer behaviour in transition economies. She teaches merchandise planning and buying, retail strategy and promotional strategies.

\section{Judith Whipple}

is an associate professor in food industry management. Her teaching interests include strategic analysis and planning, industrial management, business logistics, distribution and logistics strategy. Her research interests include supply chain integration, alliances and relationship marketing, efficient consumer response, industrial buyer behaviour and customer service/satisfaction.

\section{Amy VanAuken}

is an MS candidate in merchandising management at Michigan State University.

\begin{abstract}
In the intensely competitive food industry, increasing and sustaining repeat buying behaviour among store customers can significantly increase profits. Studies have analysed store loyalty, but no published studies have asked shoppers to define store loyalty; the authors conducted six focus group interviews with consumers in a mid-western US city, in which they investigated respondent likes and dislikes of a preferred food store and consumers' own definition of store loyalty. Participants' repeat buying behaviour was linked to multiple characteristics defining a shopping environment (eg promotion, low prices). Within the context of a customer loyalty framework, participants matched the description of spuriously loyal: high repeat patronage, but low relative attitude towards preferred stores. The results have specific implications for more profitable food store management and for further useful research on customer loyalty.
\end{abstract}

Patricia Huddleston Michigan State University, Merchandising Management, 204 Human Ecology Building, East Lansing, MI 48824, USA

Tel: +1 517353 9907; e-mail: huddles2@msu.edu

\section{INTRODUCTION}

To survive in today's competitive markets, food retailers must create and maintain a loyal customer base. When food business executives were asked to prioritise their year 2003 goals, customer loyalty and retention was most frequently mentioned (64.3 per cent of respondents). ${ }^{1}$ The US food system, as well as the global food system, has faced many challenges in the last few decades. Changing customer demographics and evolving industry and economic trends have created a more competitive food industry. Today's consumers are vastly different than, for example, consumers 50 years ago; the typical family structure of one-parent-at-home and one-parent-at-work exists in only 7 per cent of US families, ${ }^{2}$ while dual-income families account for almost 50 per cent of US households. ${ }^{3}$ Thirty-one per cent of families are single-parent households. ${ }^{4}$ These changes in family structure have a dramatic impact on the amount of time consumers spend on food purchase decisions, as well as the amount of time they are willing to spend on food 
preparation and consumption. A new group of consumers has emerged - a group that is burdened by fast-paced lives and a group that thinks of cooking as 'meal assembly', or the creation of meals by relying upon short cuts (eg complete packaged meals that require few steps and quick cooking), prepared meals and take-away options.

Along with changing family dynamics, the US population is more diverse than ever before. Groups that represent the largest population growth rates in the USA are Hispanics/Latinos and Asian Americans. Mixed ethnicity families are more common than ever before, and the multiracial population in the USA continues to climb. One of the strongest cultural markers is food consumption different geographic, cultural and ethnic groups often have different food preferences, and diversity thus requires stores to pay attention to ethnic and niche tastes. Changing family structures and evolving cultural demographics require food retailers to expand product offerings to meet the demands for more convenient food items as well as demands for a wider variety of food products. Further, these transformations require supermarkets to change traditional operations to be more convenient for customers (eg shorter checkout times, additional in-store services such as banking, better in-store customer service). ${ }^{5,6}$

Industry and economic trends have also incited change in traditional food retailing operations. In the USA, food retailers face paper-thin profit margins: the average net profit for food retailers is generally 1.25 per cent after tax. ${ }^{7}$ Shopper attrition rates are over 20 per cent per year, due in part to increased competition in the food sector and growth in retail formats. In the past two decades, completely new formats have entered the national market — such as supercentres, warehouse club stores and specialty retailers (eg pet food centres and various discount food chains) - and have created more competition for traditional food retailers. In addition, there has been substantial consolidation in food retailing. With slim profit margins, firms must focus on ways to reduce cost; economies of scale gained through consolidation and expansion efforts - represent one method for achieving cost reductions. ${ }^{8}$

Although most food retailers face thin margins and increased economic pressures, a small number of retailers has managed to claim top sales positions: the top ten supermarket chains are responsible for almost half of industry sales - and this figure does not include WalMart, whose food sales were higher in 2001 than the top US supermarket chain, Kroger. ${ }^{9}$ To compete, many retailers are creating multiple formats for their chains: for example, by investing in petrol stations or convenience stores located outside the supermarket, or investing in discount store formats. WalMart is investing in a 'Neighborhood Markets' concept to satisfy consumers who want the cost benefits of WalMart without the large size of a supercentre or warehouse club store. This expansion into multiple format retailer operations has contributed to an environment of price wars and cutthroat competition. ${ }^{10}$

Customer loyalty is a critical issue because consumers spend an average of 78 per cent of their food dollars at one primary store; ${ }^{11}$ highly loyal supermarket customers spend an average of 32 per cent more than other customers. ${ }^{12}$ Further, customer loyalty can yield favourable operating cost advantages for retailers, including streamlined inventory management, fewer markdowns and simplified capacity forecasting. Obtaining new customers costs five to six times as much as retaining current customers. If a 
business keeps an additional 5 per cent of existing customers, the total lifetime profits from a typical customer can increase by 75 per cent. ${ }^{13}$ Other benefits of having a loyal customer base include the likelihood that customers increase spending over time; loyal customers help reduce store-wide price discounts, because price promotions can be targeted to valued customers. Loyal customers refer others to the store, which builds word-of-mouth reputation and may expand the customer base. ${ }^{14,15}$

Given intense competition and ever-changing consumer dynamics, retailers must understand how consumers view supermarkets (and other competing retail formats) and focus on strategies to increase consumer satisfaction and to retain customers. With all the choices available today, retailers cannot afford to disappoint consumers - or they risk lost customers. To become the primary store for customers, retailers must develop strategies that recognise loyalty as a multifaceted and complex variable influencing customer preferences and decision making. On the surface, loyalty may appear quite simple: for example, the top three features consumers rely upon to pick a primary supermarket include a clean, neat store, high-quality fruit and vegetables and high-quality meat. ${ }^{16}$ When these features are read in light of the shifting cultural dynamics briefly discussed above and through the fierce competitive environment in which food retailers operate, it is, however, obvious that these features are not as simple as they initially seem, and that retailers require much more complex ways of understanding and assessing customer loyalty.

Although retailers understand that it is important to develop a loyal customer base, they may not necessarily understand how to accomplish this goal. A deeper understanding of what engenders store loyalty would be beneficial to food retailers in developing appropriate strategies to satisfy loyal customers and to maintain a competitive advantage. Thus, the purposes of this research are to:

1 introduce a loyalty framework and then to review loyalty literature specific to food retailing

2 identify factors that create repeat and loyal purchase behaviour

3 understand preferred food store characteristics

4 generate food shopper evaluations of food stores and apply the findings to a framework of customer loyalty ${ }^{17}$

5 recommend strategies to enhance store loyalty - through managerial techniques and with further research.

\section{CONCEPTUAL FRAMEWORK}

The conceptual base for this study is the customer loyalty framework proposed by Dick and Basu (see Figure 1), who proposed that brand (or, as relevant to this study, store) loyalty plays a special role in generating repeat purchases. ${ }^{18}$ The framework conceptualises loyalty as the relationship between relative attitude toward a brand and patronage behaviour. Relative attitude and repeat patronage behaviour signify four levels of loyalty: no loyalty (low relative attitude and low repeat patronage), spurious loyalty (low relative attitude and high repeat patronage), latent loyalty (high relative attitude and low repeat patronage) and loyalty (high relative attitude and high repeat patronage).

Dick and Basu postulated that attitudinal antecedents play a role in defining the nature of an attitude, and, as a result, its relationship to patronage behaviour. ${ }^{19}$ Cognitive antecedents are beliefs about an object (ie accessibility, confidence, centrality and clarity); affective antecedents are feelings and 


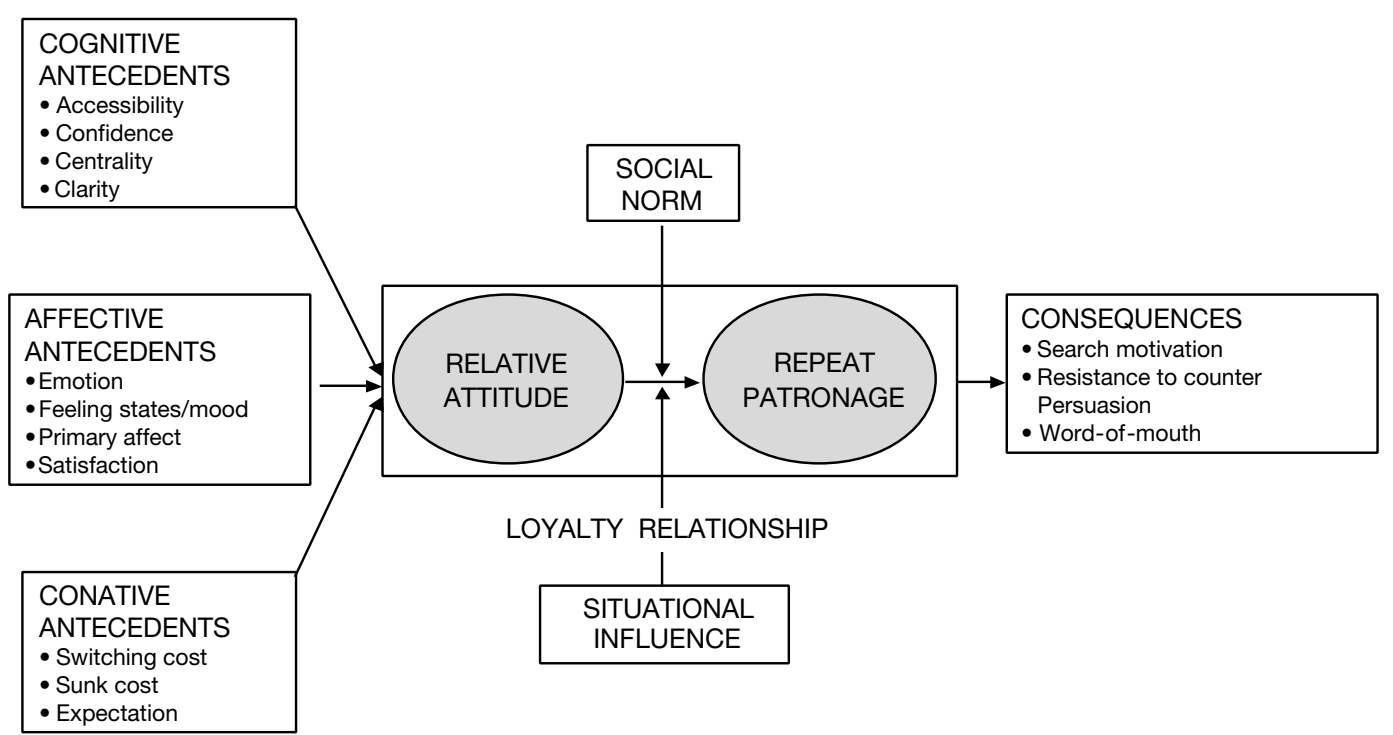

Figure 1 A framework for customer loyalty (Dick and Basu)

emotions about an object (moods, primary affect and satisfaction); conative antecedents reflect how customers respond to an object based on knowledge, feelings and expectations (eg switching costs, sunk costs, expectations). Of these, the cognitive and affective components have received the most attention from market researchers. ${ }^{20}$ Additional factors that play a role in repeat patronage are consumer social norms or situational factors; both are considered to be non-attitudinal sources of variance in purchase behaviour; at times, social norms and/or situational factors may complement or contradict an attitude and thus act as moderators of the relative attitude-repeat patronage relationship.

The Dick and Basu model identifies three consequences of customer loyalty:

1 how likely a customer is to search for an alternative (ie search motivation)

2 how resistant a customer is to counter-persuasion (eg a competing store's advertised sales) and
3 how likely a customer is to make word-of-mouth recommendations to others. $^{21}$

These three factors are closely related to consumer loyalty or relative attitude and repeat purchase; the more loyal customers are, the less likely they are to search for an alternative. The more loyal customers are, the more resistant to change they are, the more stable their behaviour will be and the more likely they are to speak favourably about a store.

\section{LITERATURE REVIEW}

\section{Store loyalty definition and measures}

Early work on brand loyalty ${ }^{22,23}$ observed that loyalty and repeat purchase behaviour are not synonymous, and that loyalty has both behavioural and psychological (decision making, evaluative) dimensions. These studies indicate that, unlike loyal purchase behaviour, repeat purchase behaviour is 
not intentional, nor does it necessarily reflect commitment or constitute loyalty. ${ }^{24}$ This key finding is noteworthy because it indicates that simple repeat purchase behaviour is not stable over the long term and may be influenced by a variety of factors.

A separate, but related, stream of research applied brand loyalty to scrutinise customer store loyalty. ${ }^{25-28}$ Early work recognised the benefit of securing a larger proportion of the 'loyal' customer's business, especially their food dollars. ${ }^{29,30}$ Commonly used measures of store loyalty focus on behaviour such as percentage of purchases at a particular store, ${ }^{31-34}$ dollars spent, ${ }^{35}$ frequency of patronage, ${ }^{36-38}$ and degree of store switching. ${ }^{39}$ Other measures have examined attitudes and intentions to continue patronage: loyalty intentions ${ }^{40-42}$ and word-of-mouth recommendations. ${ }^{43}$

Although this past research offers much insight to understanding patronage and loyalty, scant attention has been devoted to developing a common understanding and definition of store loyalty. Common, and also general, understandings define loyalty as being 'unswerving in allegiance' and 'being faithful to a cause, ideal, custom, institution, or product' (see contemporary dictionaries for more examples of general definitions). Food Business News defined customer loyalty more concisely as 'creating the strongest possible relationship between the retailer and customer, so that people feel they will miss something if they go to another store'. ${ }^{44}$ Bloemer and de Ruyter defined store loyalty even more precisely as

'The biased (i.e. non-random) behavioral response (i.e.) revisit expressed over time, by some decision making unit with respect to one store out of a set of stores, which is a function of psychological (decision making and evaluative) processes resulting in brand commitment'. ${ }^{45}$
Bloemer and de Ruyter incorporated store commitment as a necessary condition for store loyalty. In the absence of such a commitment, a shopper is simply spuriously loyal (ie high repeat visiting behaviour with low relative attitude). ${ }^{46}$ Spurious loyalty does not have the same long-term benefits to a retailer as true loyalty because there is a great likelihood that a spuriously loyal customer can be persuaded to shop elsewhere.

Researchers have examined links between store loyalty and purchase intentions, and between attitudes and perceptions of shoppers. Few studies, however, have examined how food store customers define loyalty and what motivates repeat patronage (or loyalty). Food retailing studies have focused on specific store strategies used to attract loyalty; a review of studies focused on loyalty and food retailing is provided below.

\section{Store loyalty: Attitudinal antecedents}

A growing body of empirical research has connected perceptions of store attributes and customer emotions related to the shopping experience and to store loyalty. Tangible store characteristics (merchandise assortment, store design and service) and loyalty intentions of supermarket shoppers appear to be related. Favourable perceptions of service quality, price, merchandise quality and value lead to higher loyalty intentions. ${ }^{47}$ When store atmosphere is positively evaluated, spending levels, amount of time spent in the store and willingness to visit again increase. ${ }^{48}$ Availability of store brands result in higher spending on both grocery and non-grocery items. ${ }^{49,50}$

The extant literature emphasises the influence of an emotional (affective) component to loyalty behaviour.

Satisfaction with store elements has been 
shown to elicit emotions, which in turn result in loyalty. Positive emotional responses to merchandise assortment, pricing, service and store facility are predictors of store loyalty intentions. For example, a well-designed, low-congestion store layout evokes positive emotions from consumers $;{ }^{51}$ product assortment and sales assistance also evoke emotions, which, in turn, influence attitudes towards a store, and attitudes towards a store influence loyalty. ${ }^{52,53}$ Positive emotions demonstrate stronger predictive ability of loyalty than do cognitive processes. ${ }^{54}$ Elements of the shopping experience will produce emotions that consumers may unconsciously connect to a shopping experience or to a store, ${ }^{55,56}$ for example, hearing piano music playing in the background while shopping in an immaculately clean store (eg 'the Nordstrom experience') might generate feelings of joy or contentment, and a generally positive feeling towards a store. Emotional loyalty toward services and multi-format retailers reflect consumer satisfaction, and result in positive word-of-mouth — indicating that emotional loyalty precedes loyalty behaviour. $^{57,58}$

Satisfaction with customer service affects store loyalty, and service perceptions are the most powerful predictor of loyalty. ${ }^{59}$ Developing a trusting relationship with sales personnel appears to be a key link in the development of attitudes and loyalty towards a store. Customers establish relationships with employees that may endure over time; these relationships strengthen store loyalty. Service quality influences consumer satisfaction. Satisfaction influences purchase intention and positive word-of-mouth — both indicators of store loyalty. ${ }^{60-63}$ Good training of employees - which may be as simple as encouraging staff to greet and thank customers as well as be helpful with customer requests - can make an impact on customer satisfaction and loyalty. ${ }^{64}$ Customer trust in a retailer is positively related to perceived salesperson commitment - the sense that a salesperson is committed to fulfilling shopper needs and addressing customer questions results in more positive attitudes towards a store and increased purchase intention. ${ }^{65}$ The salesperson may also be a store manager, who can be influential in a direct manner with customers, but also can serve as an indirect role model for store employees (eg by walking the floor and interacting with employees and customers). Not only can this behaviour increase customer loyalty, but it can also decrease employee turnover; ${ }^{66}$ turnover is often linked to the ability to train and maintain strong customer service orientation.

It is obvious, through this brief literature review, that store loyalty is defined in multiple ways and is the complex result of interactions between customer attitudes towards tangible and intangible store attributes. Loyalty is also tied to emotions elicited as an outcome of the shopping experience. The authors believe that gaining a deeper understanding of preferred store attributes, dislikes about the shopping experience and store loyalty will allow marketers to, first, better understand customer likes, dislikes and loyalty, and, secondly, to make recommendations that enable food stores to capture and retain loyal consumers by being better able to meet their needs.

\section{METHODS}

Because of the complex nature of loyalty and the difficulty in isolating its dimensions, a qualitative approach, focus group interviews, was employed to achieve the research objectives. 
Qualitative research methods are desirable when 'attempting to uncover the nature of a person's experience with a phenomenon' or to gain a 'novel and fresh slant on things about which quite a bit is known'. ${ }^{67}$ The majority of existing store loyalty studies employed quantitative research methods to determine how consumers define store loyalty. ${ }^{68}$ Focus groups are appropriate when profound insights into a complex problem are needed, or when it is desirable to uncover factors related to complex behaviour; ${ }^{69}$ focus groups produce richer levels of meaning, make important connections and identify nuances in expression and meaning. ${ }^{70}$ Because focus groups permit participants to describe experiences in their own words, focus group approaches enable researchers to gain an understanding of the underlying thought processes motivating behaviour.

\section{Data collection procedures}

With the assistance of a marketing research firm, screening criteria and an interview guide were developed (see Appendix). Participants had to be responsible for buying at least 50 per cent of their household food purchases. Eligible participants were screened by gender, age and income (guided by US census categories). Women were screened in two age categories (25-45 and 55-75) and two income categories $(\$ 20,000-34,999$ and $\$ 50,000+)$. Men were screened using two income levels $(\$ 20,000-34,999$ and $\$ 50,000+)$. Men were included in only two of the six focus groups because only 21 per cent of men are the primary shoppers in US households. ${ }^{71}$ As such, it was determined that men were more likely to be differentiated by purchase and loyalty behaviour based on income, rather than by age differences.
A list of consumers was purchased from a commercial firm; from that list, participants were screened and recruited until eight to ten participants per focus group agreed to participate. Prior to conducting the six focus groups, a pilot focus group was led by a professional moderator to determine necessary modifications to the interview guide. Each focus group was audiotaped and the principal investigator and a research assistant took detailed field notes as suggested by Krueger. ${ }^{72}$ Tapes were transcribed by a professional transcription service to enhance accuracy. To capture detailed responses to questions about store loyalty and to achieve triangulation of data collection, participants responded to a brief questionnaire about their definition of store loyalty, what it means to be a loyal customer, whether they were loyal to a particular food store, media used prior to shopping and whether they had loyalty cards.

\section{Data analysis}

The transcripts from each focus group were content analysed by three independent raters. The primary researcher, who was familiar with the questions asked during the focus groups and familiar with study procedures, conducted the first analysis of the transcripts. The test transcript analysed was younger women (age 25-45) with higher income $(\$ 50,000+)$; the information and themes extracted from this group were used as a point of reference for subsequent analyses. The first analysis generated 12 themes pertaining to likes, eight themes pertaining to dislikes and nine themes pertaining to loyalty. After identifying overlapping themes, descriptors of the preferred store were narrowed into seven likes, four dislikes and nine loyalty themes. Tables $1 \mathrm{a}$ and $1 \mathrm{~b}$ offer emergent 
Table 1a: Classification and characteristics of reported likes of participants' favourite stores

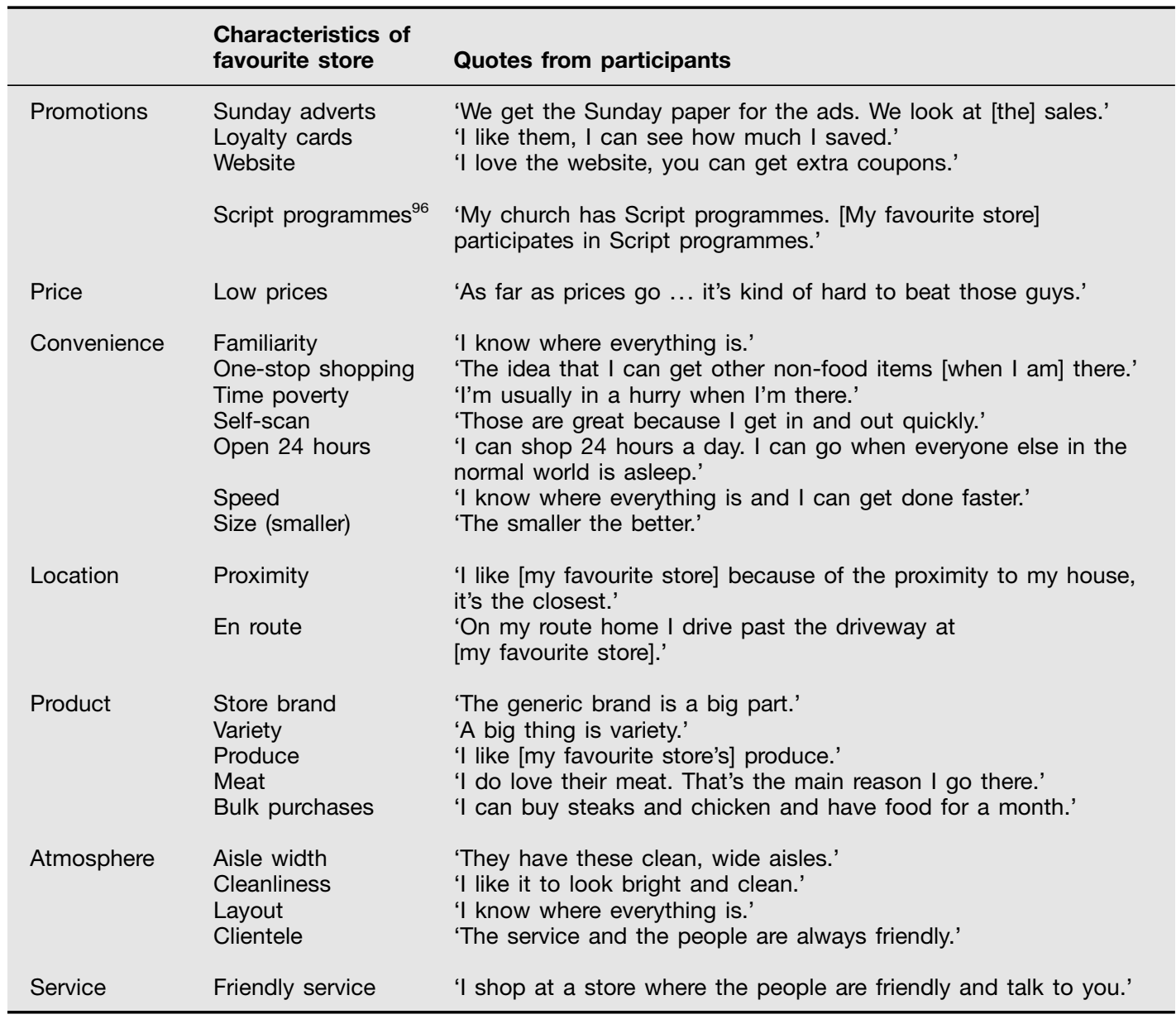

themes, characteristics of those themes, and sample quotes from focus group participants.

\section{RESULTS AND DISCUSSION}

To identify factors that create repeat and loyal purchase behaviour and to understand preferred food store characteristics, participants were asked about likes and dislikes about their preferred (favourite) store. Promotion, low prices, convenience, location, product selection, environment and service were the predominant themes for likes and dislikes.

\section{Likes and dislikes}

Promotions, for example, Sunday advertisements and loyalty cards, that provide a visible discount (via the receipt) were frequently mentioned as likes. Dislike of loyalty cards (eg loyalty cards perceived as an invasion of privacy) and inconvenient sale dates (eg sales starting on a Sunday) were factors that participants in this study responded to negatively. Advertised items being out of stock on the first and last days of the promotion was cited as especially irritating.

Offering consistently low prices was an important feature for several groups, but 
Table 1b: Classification and characteristics of reported dislikes of participants' favourite stores

\begin{tabular}{|c|c|c|}
\hline & $\begin{array}{l}\text { Characteristics of } \\
\text { favourite store }\end{array}$ & Quotes from participants \\
\hline \multirow[t]{2}{*}{ Promotion } & Loyalty cards & $\begin{array}{l}\text { 'I resent that they have to track how many Tampax I buy or what } \\
\text { kind of toilet paper I use. I feel that's going too far.' }\end{array}$ \\
\hline & Sale dates & $\begin{array}{l}\text { 'I normally go shopping on Saturdays, the last day of the sale. I } \\
\text { can't stand it if it's not stocked.' and 'I go on Sundays and they're } \\
\text { out, the first day of the sale.' }\end{array}$ \\
\hline \multirow[t]{5}{*}{ Product } & $\begin{array}{l}\text { Bad produce } \\
\text { selection }\end{array}$ & 'The produce selection is not that great.' \\
\hline & Bad meat selection & $\begin{array}{l}\text { '[My favourite store's] meat... I love to shop there but they have } \\
\text { strange meat.' }\end{array}$ \\
\hline & Package sizes & $\begin{array}{l}\text { 'It's difficult to find single person packaging. I waste money when } \\
\text { I buy larger packages.' }\end{array}$ \\
\hline & Lack of ethnic foods & 'They don't have quality ethnic foods.' \\
\hline & Brand name prices & $\begin{array}{l}\text { 'Brand names are too expensive. They hike up prices so you'll buy } \\
\text { store brands.' }\end{array}$ \\
\hline \multirow[t]{7}{*}{ Atmosphere } & Layout changes & 'I hate when they move things.' \\
\hline & Noise & 'I don't like the noise. It's not a nice ambience.' \\
\hline & Small aisles & 'I don’t like dark, narrow, crowded aisles.' \\
\hline & Crowds & 'I can’t stand crowds.' \\
\hline & Temperature & $\begin{array}{l}\text { 'In the summer, it's so wasteful when you go in and you're cold. } \\
\text { You have to put a jacket on. It's so wasteful. Sometimes, they prop } \\
\text { the doors open with the AC.' }\end{array}$ \\
\hline & Odours & $\begin{array}{l}\text { 'They have a door that you go into that takes you right into their } \\
\text { bottling area and it smells really bad.' }\end{array}$ \\
\hline & Store size (too big) & $\begin{array}{l}\text { 'It's just too big. If you forget cheese it's on the other side of the } \\
\text { store and it's quite a hike.' }\end{array}$ \\
\hline \multirow[t]{6}{*}{ Service } & Rudeness & $\begin{array}{l}\text { 'If you know you have an employee in your store who won't smile } \\
\text { and talk to the customer, there is no reason for that person to } \\
\text { be there.' }\end{array}$ \\
\hline & Long checkout lines & $\begin{array}{l}\text { 'Another thing that frustrates me is why do you build } 34 \text { lanes } \\
\text { when you are only going to have two of them open?' }\end{array}$ \\
\hline & Out of stock & $\begin{array}{l}\text { 'I go on Sundays and they're out [of stock], the first day of } \\
\text { the sale.' }\end{array}$ \\
\hline & Self-scan & $\begin{array}{l}\text { 'I don't like the new scanners where you have to do it yourself for } \\
\text { small things.' }\end{array}$ \\
\hline & Lack of employees & 'Trying to find a sales person. It's hard to find them in the store.' \\
\hline & $\begin{array}{l}\text { Parkıng } \\
\text { Department hours } \\
\text { (deli) are too short }\end{array}$ & $\begin{array}{l}\text { 'Sometimes the deli isn't open when I'm doing my shopping and } \\
\text { that frustrates me because I like to get certain kinds of cheese or } \\
\text { lunchmeat and I can't.' }\end{array}$ \\
\hline
\end{tabular}

price was not a central topic of discussion by all participants. Low prices appeared to be a factor that enticed many participants to a store, but was not a central reason for continued patronage.

Preferred convenience attributes included store location and other characteristics, such as familiarity with store layout, one-stop shopping, and being able to get in and out in a hurry. Participants mentioned that they liked to shop at stores close to home or located somewhere easily accessible on their way home. Being open 24 hours a day and providing self-scan lanes for quick checkout were conveniences referred to by all focus groups as being available at their preferred food store.

Product-related characteristics preferred by respondents included offering a wide variety of products, providing consistently fresh produce and meats, having a good store brand, making bulk items available and carrying general 
(non-food) merchandise. High-priced brand-name products, bad produce and meats, lack of ethnic foods, and lack of small package sizes (to accommodate a single person) were product-related dislikes.

Environment or atmospherics, such as cleanliness, aisle width, layout and friendly clientele, were preferred store attributes. Environmental qualities that participants responded to negatively included noise from announcements and music, small or narrow aisles, too hot or too cold temperatures, bad odours from bottle returns, size of store (eg too big), too busy or crowded and layout changes.

Having friendly store personnel was an important service characteristic to some participants. Service-related dislikes frequently mentioned by participants included long checkout lines, out-of-stock merchandise, lack of and/or rude employees, inconvenient hours in some departments (eg deli) and self-scanners.

\section{Preferred store characteristics: Relative attitude components}

The findings summarised above provide evidence of the attitude antecedents introduced earlier.

Consistency among antecedents is important to the development of relative attitude, ${ }^{73}$ but consistency among the dimensions introduced earlier cognitive, affective and conative - was not established by the results. Overall, cognitive antecedents held the weakest path to relative attitude about a preferred store (mentioned less frequently), whereas affective and conative antecedents were more influential in creating repeat patronage or provoking a tendency to switch, as most dislikes were affective or conative in nature. Social norms and situational factors also influenced participant attitudes towards their favourite store. Although participants struggled to provide a concrete definition of store loyalty, most were able to list characteristics that they felt made them a loyal customer.

\section{Cognitive components}

Respondents were capable and motivated to think about food shopping; in fact, many stated that they thought about grocery shopping and were list makers, evidence of being cognitively motivated, for example, 'I have a little list on the wall on the kitchen that when I run out of something, it goes on there.' Some respondents, even though they claimed they seldom thought about shopping, specified that they too kept running lists.

Attitudes towards preferred stores demonstrated accessibility (easy retrieval from memory) and confidence (they had direct experiences that they were ready and willing to share). Cognitive attitudes towards preferred stores did not, however, reveal a high level of centrality (evoking extreme relationships such as high or low loyalty). The majority of respondents indicated that they would be willing to shop elsewhere if a new competitor entered the market, suggesting they would be susceptible to persuasion. Nor did their cognitive attitudes demonstrate clarity; if an opposing viewpoint about a respondent's preferred store was offered, the respondent holding the positive view did not rigorously defend his/her position and often agreed with negative comments about the preferred store.

\section{Affective components}

The affective components of participants' attitudes were frequently articulated as negative affect, particularly concerning dislikes about preferred stores. Emotional responses such as 'I'd rather have a root canal than shop at Store A' or 'I hate when they move things' (around within 
the store) are two examples of negative affect that emerged from focus group discussions.

Moods or feeling states are not as powerful as emotions, but may influence loyalty because they can make a shopping experience memorable. ${ }^{74}$ Physical characteristics of the store influenced shopper moods: store environment and atmospherics, discussed earlier and including noise and temperature, evoked negative feelings from many participants. Although environmental designs that bring about good moods may strengthen attitude-behaviour relationships ${ }^{75}$ the converse is also true: environmental designs that evoke negative feelings weaken attitude-behaviour relationships.

Physiological affect was aroused by bad smells (eg odours from bottle return areas) and from physical cues such as crowded aisles and inconsistent temperature. Other physiological factors mentioned by participants included fluorescent lighting being 'frustrating' and physical barriers prohibiting mobility within the store. Respondents expressed irritation when employees conducted shelf replenishment or cleaned aisles without acknowledging that they were inconveniencing customers, and when the stockers did not offer to accommodate their need to gain access to products.

\section{Conative components}

Participants talked about conative antecedents in light of importance of convenience (location) and familiarity. Store re-merchandising that interfered with convenience and familiarity were met with derision. Switching costs and sunk costs were reflected in the animated way respondents discussed their dislike of layout changes ('I hate when they move things'). Taking time and energy to develop a new mental map of store layout was undesirable to participants and disrupted their desire to shop in a familiar environment. Product assortment changes were annoying for some. One respondent spoke of this in relation to her elderly mother: 'One of my dislikes is that they'll carry a product for a while ... An example is Puffs Kleenex ... she can't understand why when she bought something once she can't go back and buy it again even if it's ten years ago'.

\section{Social norms and situational factors}

Regardless of age or income level, social and situational factors influenced food shopping. Husbands and wives influenced one another not only about where to shop but what to buy. One participant noted: 'My husband has been shopping at Store A since he was born'. Children influenced parents in product selection, and some respondents shopped for groceries based on children's wishes (eg 'My kids are my main influence, primarily my daughter ... because Store A is her favourite place to go. I don't know why and I don't think she does either'). Friends shared information about weekly specials, sometimes calling one another to share this knowledge.

Situational factors such as holidays influenced participant food shopping choices, sometimes away from their preferred food store. For example, lack of traditional ethnic foods motivated some to shop elsewhere, at a store other than their preferred store. Other respondents were influenced by the day of the week ('I normally go shopping on Saturdays, the last day of the sale. I can't stand it if it's not stocked').

\section{Defining store loyalty}

Participants had a difficult time articulating a definition of store loyalty, or describing what being a loyal customer meant to them. It was easier for respondents to cite store 
characteristics that made them a loyal customer. Conative antecedents dominated store loyalty definitions; for example, consistent and frequent patronage, spending a majority of dollars (at one store), referring others (positive word-of-mouth) and shopping habit were conative dimensions that participants mentioned. Affectively-based loyalty themes elicited from the data included a level of trust in and commitment to a preferred food store.

For many participants, consistent patronage meant shopping at a store on a regular basis: 'consistently going to the same store even if the price is lower somewhere else' and 'shopping at particular stores on a regular basis'. Several participants who spent the majority of their food dollars at a particular store viewed dollars spent as loyalty. Some associated loyalty with frequency of visits to a store, or routinely choosing to shop at a particular store (eg 'going to a place an average of once a week' or 'repeat business to an establishment' or 'routinely shopping at one store without concern for price differences'). One participant stated that loyalty meant 'using the same stores for a vast majority of your needs'. The idea of loyalty as affective (such as commitment to a store) was expressed by a few participants: 'giving them my business no matter what, I won't take my business elsewhere' and 'shopping there regardless of price or location'. Fewer than five out of about 50 participants viewed loyalty in this light, however.

The Dick and Basu ${ }^{76}$ framework presents relative attitude as a result of the interaction between cognitive, affective and conative antecedents and influenced by social norms and situations. Dick and Basu postulated that relative attitudes lead to repeat patronage. Based on the data from this study, the repeat patronage of respondents reflected spurious loyalty; that is, they continue to shop at their preferred store (high repeat patronage), but could be persuaded to shop elsewhere given the opportunity (low relative attitude). An indicator of low commitment to a store was the fact that nearly all shopped at two to four stores on a regular basis. Most respondents made statements that described themselves as loyal to a food store, but as the data suggest, their definition of loyalty matches Dick and Basu's 'spurious loyalty'. The respondents to the present study found a store that 'worked for them' and it appears that they would not seek another alternative as long as they are satisfied. Inertia, or simple repeat purchase behaviour, may be a primary component of spurious loyalty. As Solomon ${ }^{77}$ points out, consumers who shop out of inertia are susceptible to marketing efforts and may be persuaded to switch stores; thus food retailers must remain vigilant in order to retain their 'spuriously loyal' customers.

The majority of respondents said they were satisfied with their preferred food store, but this repeat patronage may reflect taking the path of least resistance: they are satisfied with their current store, but willing to switch if 'something better came along'. Satisfaction did not imply commitment to a store either, with many respondents stating that they could be persuaded to shop elsewhere. In 2002, a new food store entered the geographic area of respondents in the study. Almost all had tried shopping at the new store and some had switched their shopping preference to the new entrant.

The outcomes or consequences of repeat patronage are propensity to engage in search motivation, ability to resist counterpersuasion and willingness to make word-of-mouth recommendations. Respondents did not reveal a tendency to provide positive word-of-mouth evaluations. Further, their behaviour 
suggests a 'status quo bias', ${ }^{78}$ in that they did not express a strong motivation to search for an alternate shopping venue. But they did seem to have a low resistance to counterpersuasion because of their stated willingness to shop elsewhere if a more attractive alternative was presented.

\section{DISCUSSION AND MANAGERIAL IMPLICATIONS}

Although there is a substantial body of literature on store loyalty, this study makes several important contributions. It is the first to ask food shoppers directly to characterise store loyalty. A compelling finding is that store loyalty may be more complex and difficult to pinpoint than previous research has indicated. Common measures of loyalty used by retailers and researchers (eg repeat purchases) did not necessarily imply loyalty to the sample. The study sample was unique in that both men's and women's opinions about food shopping and store loyalty were solicited. The findings about spurious loyalty were consistent for both men and women. Statistics point out that men spend about 30 per cent more than women per week on food shopping, ${ }^{79}$ yet there is a dearth of research on men's shopping habits. Further study of men's food shopping and loyalty behaviour may be fruitful.

Another contribution of this work is the discovery of a relatively good fit of these findings to the Dick and Basu ${ }^{80}$ customer loyalty framework. Evidence was found to support the proposed interaction among the relative attitude antecedents, situational influences and social norms that result in repeat patronage. The findings about store likes and dislikes are, however, both interesting and confounding; many of the characteristics participants mentioned as likes were also mentioned when discussing dislikes; for example, aisle width, produce and meats (freshness) and self-scanners were mentioned as both likes and dislikes.

Participants pointed out that their favourite store was familiar, convenient, consistent, clean and employed friendly people; these characteristics (likes) motivated their repeat purchase behaviour. The majority of participants discussed attributes that would be classified under the convenience theme as what they liked most about their preferred store. The preferred store characteristics of the sample were similar to those mentioned by other researchers: product quality, prices, ${ }^{81}$ service, ${ }^{82-84}$ and environmental factors. ${ }^{85-86}$ Presence of store brands did not seem to influence store preference, contradicting Corstjens and $\mathrm{Lal}^{87}$ It was important to a few respondents that their favourite store stock store brands, but was not a strongly preferred store characteristic. Price, one-stop shopping, product variety, store environment and service were the most frequently identified characteristics that drew participants to their preferred store.

The findings confirm previous work showing that perceptions of atmosphere play a role in eliciting emotions from customers. ${ }^{88,89} \mathrm{~A}$ well-designed store layout evoked positive emotions from the sample; for example, many mentioned that they 'love' the wide aisles in their preferred store. Familiarity with store layout and store features also emerged as a strongly preferred quality for food shoppers. A store with a consistent layout in different geographical areas and stores with wide aisles and less congestion are more likely to satisfy customers.

Previous research has not thoroughly investigated consumer dislikes about preferred food stores. It is interesting that the most frequent and vehement dislikes of participants related to store environment. Negative emotions were 
elicited when there were changes to a familiar store environment; changing store layouts destroyed customer familiarity with the store, causing them to feel frustrated and, in some cases, angry. Positive perceptions of store atmosphere have been shown to lead to increased spending, length of time spent in the store and willingness to

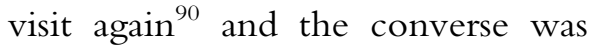
found to be true: if respondents perceived the store atmosphere negatively, they would leave the store quickly or seek another shopping venue. Consumer dislikes may provide a partial explanation for the 'low relative attitude' of spurious loyalty and should be explored more thoroughly.

Although previous literature $\mathrm{e}^{91-94}$ has identified strong links between personal service and store loyalty, service was not frequently mentioned by respondents as a loyalty-engendering store characteristic.

Service was perceived as overall store environment, and the sample sought a 'willingness to help' and 'friendly service' rather than a high level of personal service. Yet, service was repeatedly mentioned when participants were asked about what they disliked about their favourite store. Many pointed out that there were not enough checkout lines open during busy times, that store employees were not very helpful and that self-scanners created numerous problems with service availability. Apparently, good service is expected, but does not necessarily create store loyalty. Poor service, however, will definitely drive customers away.

Notably absent from the participants was a strong sense of affiliation or tie to a particular store; evidence of a strong relationship between respondents and their preferred store was not found. If a retailer could create such a relationship, it would produce a formidable strategic advantage. Perhaps the absence of a strong relationship is due to the nature of food shopping; although food shopping is a frequent activity, most people do not enjoy it. ${ }^{95}$ Better understanding how cognitive, affective and conative variables influence enjoyment, or lack thereof, of shopping experiences warrants further investigation.

Further qualitative examination of the cognitive, affective and conative dimensions that influence repeat patronage of food stores is also suggested. The desired outcome of such studies would be, if possible, to isolate loyal customers and uncover the factors that differentiate them from those customers who are spuriously loyal. Clearly, continued patronage and spending a majority of food dollars do not definitively reflect loyalty.

Future exploration of food store loyalty should also measure the propensity to switch shopping venues, for example, understanding the circumstances under which a frequent shopper is willing to shop elsewhere would be useful in assessing whether such behaviour reflects true or spurious loyalty. Instruments should utilise multidimensional measures of loyalty and include items that measure commitment to continue patronage. Comparing loyalty by a variety of retail formats might be a fruitful avenue for further study; for example, several participants expressed loyalty to smaller local markets that offered a good selection of ethnic and specialty products (eg fine wine). This loyalty, however, appeared to be situational (eg related to a holiday). Studies that have examined store loyalty often have focused on larger chain stores and supermarkets, mainly because they are readily accessible and provide a larger venue through which to conduct research. Loyalty in regard to smaller stores must also be assessed however; research might focus on whether or not 
the same frameworks and suggestions apply to both large supermarkets and smaller specialty formats.

Another path for academics and practitioners to investigate is the role of store irritants in driving repeat customers into the arms of the competition. In this study, participants characterised loud overhead announcements and distracting music as dislikes. Although self-serve bottle returns have become the norm and promise shoppers faster, more convenient service in bottle-return areas and other areas of the store, participants in the study noted that self-serve bottle-return areas were not liked, mainly because of bad smells. Rather than inviting customer opinions about what the retailer is doing right, the loyalty payoff might be greater if customers are asked to identify what they are doing wrong — then fixing the problems.

Food retailers should take heed, and not assume that frequent shoppers are loyal shoppers. Customers who say that they are loyal to a store might, in their next breath, say they can be persuaded to shop elsewhere. Entry of new market competitors should be closely monitored to determine their potential to lure away current customers. Respondents indicated willingness to try shopping at a new food store, but a new venue is usually given one chance to 'prove' itself as superior; even if a shopper forsakes a preferred store, they will return if the new store does not meet expectations. Numerous comments about a recent market entrant led participants in the study to make comments like: 'I tried it once, I'll never go back'. Thus, stores should work to understand what characteristics might entice shoppers to try a competitor and what tactics work best to draw them back and retain their patronage and loyalty.
A strategic challenge for food retailers is that most of the preferred store characteristics identified by participants in this study are easily copied by the competition. Pricing policies and product assortments can be imitated, but food retailers can invent ways to make customers feel an affinity for their store, perhaps by creating a retail brand through a consistent store layout. For supermarkets with multiple units in a geographic area, establishing a 'branded' store layout would reassure shoppers that regardless of location they can easily find their way toward and through a store. Competitors may find it difficult to imitate a unique store environment, because creating a unique environment involves the thoughtful and complex integration of store operations, store environment and service personnel.

The most compelling question that this study raises, and a crucial path for future research, is whether or not loyal food store customers even exist. Are all food store customers, instead, just repeat customers? Are they status quo shoppers who rely upon a store merely for convenience, rather than out of a sense of loyalty? Are they customers always up for grabs in a competitive market because they are continually ready to try something new?

In a world in which family and cultural dynamics are constantly shifting, and at a time when many stores face fierce competition, one core anchor remains strong: people need to eat and people need to shop for food. Relying upon that core biological fact, however, without consideration of the complicated interplay of situational and social components that affect shopper perceptions of a store and their sense of store loyalty may be the distinguishing factor between stores that survive and thrive in the midst of larger social and economic change, and stores that 
disappear - that become victims of a competitive market.

\section{APPENDIX: FOOD STORE LOYALTY INTERVIEW GUIDE}

1 Where do you shop most often for food?

2 Where do you prefer to do your food shopping?

General discussion of food shopping

3 How much/little do you think about food shopping?

Occasion/routine/scheduled

4 Write down the top two or three reasons why you shop at your preferred store.

5 Write down one or two things you dislike about your preferred store.

6 Describe your best/worst food shopping experiences.

7 Impressions of your 'preferred' food store.

8 How often do you shop for food?

9 How many stores do you normally visit to fulfil your food needs?

10 About how much do you spend per week on food?

11 How much of that do you spend at your preferred store? (If not the majority of expenditures, why not?)

12 Does anyone influence where you shop for food (opinion leaders, gate keepers)?

Store loyalty

You filled out a questionnaire when you came in about store loyalty. Let's talk for a few minutes about this idea of 'loyalty to a store'.

13 What does 'loyalty' mean to you (time/\$ spent/other)?

14 Do you make any trade-offs when you shop at your preferred store vs other options?

15 How satisfied/dissatisfied are you with your preferred/most often shopped store?

16 How loyal are you to your 'preferred' or most often shopped store (for example, how easy would it be to get you to shop at another store and what would persuade you to do so)?

17 What is one thing that your 'preferred' store can do to keep your business? (Or what do you wish they would do?)

\section{References}

1 'Top of Mind 2003' (2003) Food Business News Plus, Vol. 30, January, pp. 1-4.

2 Senauer, B., Asp, E. and Kinsey, J. (1991) 'Food trends and the changing consumer', Eagan Press, St. Paul, Minnesota.

3 Kearney, A. T. and Grocery Manufacturers of America (1999) 'Future forces and the new consumer', unpublished report prepared for the Future Forces Roundtable, October.

4 Fields, J. and Casper, L. M. (2001) 'America's families and living arrangements', Current Population Reports. US Bureau of the Census, June, http://www.census.gov/prod/2001pubs/p20-537.pdf (Accessed 10th March, 2003).

5 'The convenient center' (1999) Supermarket Business, Vol. 54, No. 10, October, pp. 41, 44.

6 Food Marketing Institute (2001) 'Trends in the United States: Consumer attitudes and the supermarket', Research Department, Washington, DC.

7 Food Marketing Institute (2002) 'Supermarket facts: Industry overview', http://www.fmi.org/facts_figs/ superfact.htm (Accessed 13th April, 2002).

8 Shultz, D. M., Blackburn, M. and Iannaconi, T. (2001) 'The beans are about to be counted differently', Brandmarketing, Vol. 23, December, p. 23.

9 Retail Forward (2002) 'Industry outlook: Food channel', Columbus, Ohio.

10 Ibid.

11 Food Marketing Institute (2001) op. cit.

12 East, R., Harris, P., Willson, G. and Lomax, W. (1995) 'Loyalty to supermarkets', International Review of Retail, Distribution and Consumer Research, Vol. 5, No. 1, pp. 99-109.

13 Reichheld, F. E. (1996) 'The loyalty effect: The hidden force behind growth, profits and lasting value', Harvard University Press, Boston, Massachusetts.

14 Baloglu, S. (2002) 'Dimensions of customer loyalty: Separating friends from well wishers', Cornell Hotel and Restaurant Administration Quarterly, Vol. 43, No. 1, pp. 47-57.

15 Curasi, C. F. and Kennedy, K. N. (2002) 'From prisoners to apostles: A typology of repeat buyers and loyal customers in service businesses', Journal of Services Marketing, Vol. 16, No. 4, pp. 322-341.

16 Food Marketing Institute (2001) op. cit.

17 Dick, A., and Basu, K. (1994) 'Customer loyalty: 
Toward an integrated conceptual framework', Journal of the Academy of Marketing Science, Vol. 22, April, pp. 99-113.

18 Ibid.

19 Ibid

20 Weiner, J. (1998) 'Nice attitude: Get more from your research', Marketing News, Vol. 32, No. 1, p. 13.

21 Dick and Basu (1994) op. cit.

22 Jacoby, J. and Kyner, D. B. (1973) 'Brand loyalty vs. repeat purchasing behavior', Journal of Marketing Research, Vol. 10, February, pp. 1-9.

23 Jarvis, L. P. and Wilcox, J. B. (1977) 'True vendor loyalty or simply repeat purchase behavior?', Industrial Marketing Management, Vol. 6, pp. 9-14.

24 Ibid.

25 Charlton, P. (1973) 'A review of shop loyalty', Journal of Market Research Society, Vol. 15, No. 1, pp. $35-51$.

26 Cunningham, R. M. (1962) 'Customer loyalty to store and brand', Harvard Business Review, Vol. 40, Nov.-Dec., pp. 127-137.

27 Enis, B. M. and Paul, G. W. (1970) 'Store loyalty as a basis for market segmentation', Journal of Retailing, Vol. 46, No. 3, pp. 42-56.

28 Tate, R. S. (1961) 'The supermarket battle for store loyalty', Journal of Marketing, Vol. 25, pp. 8-13.

29 Cunningham (1962) op. cit.

30 Enis et al. (1970) op. cit.

31 Cunningham (1962) op. cit.

32 Dunn, R. and Wrigley, N. (1984) 'Store loyalty for grocery products: An empirical study', Area, Vol. 6, pp. $307-314$

33 Macintosh, G. and Lockshin, L. S. (1997) 'Retail relationships and store loyalty: A multi-level perspective', International Journal of Research in Marketing, Vol. 14, pp. 487-497.

34 Sirohi, N., McLaughlin, E. W. and Wittink, D. R. (1998) 'A model of consumer perceptions and store loyalty intentions for a supermarket retailer', Journal of Retailing, Vol. 74, No. 2, pp. 223-245.

35 Corstjens, M. and Lal, R. (2000) 'Building store loyalty through brands', Journal of Marketing Research, Vol. 38, August, pp. 281-291.

36 Kelley, R. F. (1967) 'Estimating ultimate performance levels of new retail outlets', Journal of Marketing Research, Vol. 4, pp. 13-19.

37 Seiders, K. and Tigert, D. J. (1997) 'Impact of market entry and competitive structure on store switching/store loyalty', The International Review of Retail, Distribution and Consumer Research, Vol. 7, No. 3, pp. 227-247.

38 Thompson, B. (1967) 'An analysis of supermarket shopping habits in Worcester, Massachusetts', Journal of Retailing, Vol. 43, No. 3, pp. 17-29.

39 Farley, J. V. (1968) 'Dimensions of supermarket choice patterns', Journal of Marketing Research, Vol. 5, May, pp. 206-208.

40 Macintosh and Lockshin (1997) op. cit.

41 Sirohi et al. (1998) op. cit.

42 Zins, A. (2001) 'Relative attitudes and commitment in customer loyalty models', International Journal of
Service Industry Management, Vol. 12, No. 3, pp. 269-294.

43 Sirohi et al. (1998) op. cit.

44 'The route to customer loyalty — tying the customer to the store' (1998) Food Business News, Vol. 9, January, pp. 1-4.

45 Bloemer, J. and de Ruyter, K. (1997) 'On the relationship between store image, store satisfaction and store loyalty', European Journal of Marketing, Vol. 32, No. 5/6, pp. 499-513.

46 Ibid.

47 Sirohi et al. (1998) op. cit.

48 Donovan, R. J. and Rossiter, J. R. (1982) 'Store atmosphere: An environmental psychology approach', Journal of Retailing, Vol. 58, Spring, pp. 34-57.

49 Corstjens and Lal (2000) op. cit.

50 Ailawadi, K., Neslin, S. A. and Gedenk, K. (2001)

'Pursuing the value conscious consumer: Store brands versus national brand promotions', Journal of Marketing, Vol. 65, January, pp. 71-89.

51 Yoo, C., Park, J. and Maclnnis, D. (1998) 'Effects of store characteristic and in-store emotional experience on store attitude', Journal of Business Research, Vol. 42, pp. 253-263.

52 Grewal, D., Krishnan, R., Baker, J. and Borin, N. (1998) 'The effect of price discount, brand and store information on consumers' product evaluation and purchase intentions', Journal of Retailing, Vol. 74, No. 3, pp. 331-352.

53 Yoo and MacInnis (1998) op. cit.

$54 \mathrm{Yu}, \mathrm{Y}$. and Dean, A. (2001) 'The contribution of emotional satisfaction to consumer loyalty', International Journal of Service Industry Management, Vol. 12, No. 3, pp. 234-250.

55 Yoo and MacInnis (1998) op. cit.

56 Chang, E. S., Wang, Y. and Huddleston, P. T. (2001) 'Influences on Korean consumers' store loyalty intentions toward super-discount stores', Proceedings of the 11th International Conference on Research in the Distributive Trades, Tilburg, Netherlands, pp. D-3.1

57 Mugica, J., Berné, C., Arrondo, E. and Rivera, P. (2001) 'Modeling of customer retention in multi-format retailing', Proceedings of the 11th International Conference on Research in the Distributive Trades, Tilburg, Netherlands, p. C2.3.

$58 \mathrm{Yu}$ and Dean (2001) op. cit.

59 Chang et al. (2001) op. cit.

60 Boulding, W., Kalra, A., Staelin, R. and Zeithamal, V. (1993) 'A dynamic process model of service quality: From expectations to behavioral intentions', Journal of Marketing Research, Vol. 30, No. 1, pp. 7-21.

61 Taylor, S. A. and Baker, T. L. (1994) 'An assessment of the relationship between service quality and customer satisfaction in the formation of consumers' purchase intentions', Journal of Retailing, Vol. 70, No. 2, pp. 63-179.

62 Sirohi et al. (1998) op. cit.

63 Zins (2001) op. cit.

64 Food Marketing Institute (2001) op. cit. 65 Macintosh and Lockshin (1997) op. cit. 
66 Food Marketing Institute (2001) op. cit.

67 Strauss, A. and Corbin, J. (1990) 'Basics of qualitative research: Grounded theory procedures and techniques', Sage Publications, Newbury Park, California.

68 Siohi et al. (1998) op. cit. is an exception.

69 Krueger, R. A. (1998) 'Developing questions for focus groups', Sage Publications, Thousand Oaks, California.

70 Stewart, D. W. and Shamdasani, P. N. (1990) 'Focus groups: Theory and practice', Sage Publications, Newbury Park, California.

71 Fetto, J. (2002) 'Guys who shop', American Demographics, November, p. 16.

72 Krueger (1998) op. cit.

73 Dick and Basu (1994) op. cit.

74 Ibid.

75 Ibid.

76 Ibid.

77 Solomon, M. R. (1992) 'Consumer behavior', Allyn \& Bacon, Boston, Massachusetts.

78 Rhee, H. and Bell, D. R. (2002) 'The inter-store mobility of supermarket shoppers', Journal of Retailing, Vol. 78, No. 4, pp. 225-237.
79 Fetto (2002) op. cit.

80 Dick and Basu (1994) op. cit.

81 Sirohi et al. (1998) op. cit.

82 Bloemer and de Ruyter (1997) op. cit.

83 Boulding et al. (1993) op. cit.

84 Sirohi et al. (1998) op. cit.

85 Mugica et al. (2001) op. cit.

$86 \mathrm{Yu}$ and Dean (2001) op. cit.

87 Corstjens and Lal (2000) op. cit.

88 Yoo et al. (1998) op. cit.

$89 \mathrm{Yu}$ and Dean (2001) op. cit.

90 Donovan and Rossiter (1982) op. cit.

91 Boulding et al. (1993) op. cit.

92 Taylor and Baker (1994) op. cit.

93 Sirohi et al. (1998) op. cit.

94 Zins (2001) op. cit.

95 Food Marketing Institute (2002) op. cit.

96 A script programme is a form of financial sponsorship which allows a non-profit organisation (eg a local school or church) to receive a percentage of what is spent by their customers. For example, parents of a student in a local school turn in their receipts to the store and the school receives a financial reward, based on the parents' expenditures. 